\title{
UPAYA MENINGKATKAN HASIL BELAJAR IPA DENGAN METODE DEMONSTRASI PADA SISWA KELAS VI SDN 1 UBUNG TAHUN PELAJARAN 2018/2019
}

\author{
Muhammad \\ Guru SD Negeri 1 Ubung Lombok Tengah
}

Abstrak. Penelitian ini bertujuan untuk mendapatkan informasi yang akurat tentang penerapan metode demonstrasi pada pembelajaran IPA dalam meningkatkan hasil belajar siswa kelas VI SDN 1 Ubung Tahun Pelajaran 2018/2019. Metode yang digunakan dalam penelitian ini adalah metode deskriptif dan bersifat kolaboratif, sampel penelitian adalah siswa dan guru kelas VI SDN 1 Ubung. Rendahnya hasil belajar IPA siswa kelas VI SDN 1 Ubung, Kecamatan Jonggat, Kabupaten Lombok Tengah menjadi latar belakang dilakukan penelitian ini. Hal ini terjadi sebagai akibat kurang maksimal kemampuan guru dalam menggunakan model pembelajaran dan penggunaan media belajar ketika kegiatan belajar mengaja berlangsung. Penelitian dilaksanakan dalam empat tahap kegiatan yaitu Perencanaan tindakan, pelaksanaan tindakan, observasi dan refleksi dilaksanakan dua siklus kegiatan. Hasil penelitian menunjukkan bahwa aktivitas guru dan aktivitas siswa mengalami peningkatan pada setiap siklus. Peningkatan tersebut menunjukan bahwa pada aktivitas guru dan siswa pada siklus 1 masuk kategori baik dan pada siklus II aktivitas guru dan siswa berada dalam kategori sangat baik. Adapun hasil belajar siswa pada siklus I pertemuan 1 dilihat dari ketuntasan klasikal adalah $25 \%$ (6 dari 24 siswa), pada siklus I pertemuan 2 meningkat menjadi 50\% (12 dari 24 siswa), pada siklus II pertemuan 1 meningkat menjadi 75\% (18 dari 24 siswa) dan pada siklus II pertemuan 2 semakin meningkat menjadi 92\% (22 dari 24 siswa). Dengan demikian penggunaan metode demonstrasi dapat meningkatkan hasil belajar siswa kelas VI SDN 1 Ubung pada mata pelajaran IPA.

Kata Kunci : Hasil Belajar, Metode Demonstrasi, IPA

\section{PENDAHULUAN}

Pada hakikatnya pendidikan dapat diartikan sebagai suatu usaha manusia untuk menjadikan manusia ke arah yang lebih baik atau lebih positif, agar tujuan pendidikan itu dapat tercapai secara maksimal, maka tentunya sebagai seorang guru dituntut untuk dapat mengembangkan suatu metode dan media pembelajaran agar kesulitan-kesulitan yang dialami siswa dapat terselesaikan. Dalam setiap kegiatan belajar mengajar ada tiga aspek yang dicapai dalam diri peserta didik yaitu perubahan aspek kognitif, perubahan aspek afektif dan aspek psikomotor. Perubahan yang dimaksud dari aspek tersebut adalah suatu proses ke arah perkembangan individu dalam mencapai tingkat kematangan baik aspek jasmani maupun rohani (Suprijono, 2011: 39).

Pembelajaran IPA merupakan ilmu pengetahuan yang mengembang-kan peserta didik untuk berfikir rasional dan ilmiah. Maka pelajaran IPA yang meliputi penguasaan konsep, ketrampilan pengetahuan alam dan sikap ilmiah diupayakan memperoleh hasil maksimal. Penggunaan metode demonstrasi pada pelajaran IPA dimaksudkan untuk menggairahkan belajar peserta didik. Dengan bergairahnya belajar peserta didik merupakan tujuan yang diikuti upaya peningkatan kualitas pembelajaran. (Trianto, 2010: 137).

Hasil belajar IPA peserta didik kelas VI SDN 1 Ubung pada Tahun Pelajaran 2018/2019 terbilang rendah. Fakta rendahnya itu dapat dibuktikan dari hasil nilai ulangan tengah semester IPA yakni nilai terendah 47, nilai tertinggi 84 dan nilai rata - rata 57. Dari ulangan akhir semester II memperoleh nilai terendah 51, nilai tertinggi 90 dan nilai rata - rata 59, sehingga dari hasil analisa nilai ulangan tengah dan nilai ulangan akhir semester dapat disimpulkan bahwa nilai terendah adalah 49, nilai tertinggi 87 dan nilai rata - rata 58, sehingga belum mencapai standar kriteria ketuntasan minimal yang telah ditetapkan, yakni 
65. Hal ini disebabkan oleh kurangnya partisipasi dan pemahaman siswa dalam kegiatan pembelajaran, siswa cenderung hanya menerima materi yang disampaikan dan tidak melakukan kegiatan yang dapat meningkatkan pemahamannya.

Dampak yang akan timbul jika tidak segera diberikan tindakan atau menentukan serta memilih strategi yang cocok maka pemahaman siswa tentang materi yang disampaikan akan susah untuk dipahami oleh siswa. IPA merupakan materi pelajaran yang bersifat abstrak, jadi perlu adanya kegiatan yang dapat memudahkan siswa untuk lebih memahami materi.

Oleh karena itu diperlukan suatu metode yang dapat memudahkan siswa untuk memahami materi yang sedang dipelajari, yaitu dengan menggunakan metode demonstrasi sehingga pemahaman yang abstrak akan menjadi konkret karena siswa dapat mendemonstrasikan dan ini akan memudahkan siswa untuk memahami materi yang disampaikan. Menurut Dr. Wina Sanjaya, bahwa metode demonstrasi adalah metode penyajian pelajaran dengan memperagakan dan menunjukkan kepada siswa tentang suatu proses, situasi atau benda tertentu, baik sebenarnya atau hanya sekedar tiruan.

Berdasarkan permasalahan yang ada dalam proses pembelajar-an khususnya IPA maka peneliti berkolaborasi dengan para guru mencoba untuk meneliti tentang kegiatan pembelajaran pada mata pelajaran IPA melalui penggunaan metode demonstrasi yang menjadi latar belakang masalah dan berguna untuk memperbaiki proses pembelajaran dan peningkatan hasil belajar siswa yang lebih baik lagi.

\section{METODE PENELITIAN}

Penelitian ini dilaksanakan pada bulan Agustus hingga September 2018. Penelitian ini dilatarbelakangi oleh permasalahan yang terjadi di kelas VI SD Negeri 1 Ubung yaitu rendahnya hasil belajar siswa pada mata pelajaran IPA.

Jenis penelitian ini adalah penelitian tindakan kelas. Langkah-langkah tindakan yang ditempuh merupakan kerja yang berulang Jurnal Pendidikan Mandala (siklus-siklus) sebagaimana yang dikembangkan oleh Kenmis dan MC. Taggar yaitu perencanaan, tindakan, observasi dan refleksi, hingga diperoleh pembelajaran yang dapat meningkatkan hasil belajar IPA siswa SDN 1 Ubung.

Subjek penelitian ini adalah siswa kelas VI SD Negeri 1 Ubung Tahun Pelajaran 2018/2019. Pemilihan subyek ini didasarkan pada pertimbangan guru bidang studi bahwa kelas VI memiliki hasil belajar yang kurang dalam pelajaran tersebut. Diharapkan dengan metode demonstrasi ini, hasil belajar siswa kelas VI dapat lebih meningkat. Jumlah siswa kelas VI berjumlah 24 orang anak.

Perencanaan yaitu menyusun rencana yang akan dikembangkan di dalam pembelajaran. Perencanaan ini disusun secara fleksibel untuk mengan-tisipasi berbagai pengaruh yang timbul dilapangan, sehingga penelitian ini dapat dilaksanakan secara efektif.

Pelaksanaan Tindakan, yaitu praktek pembelajaran nyata berdasarkan rencana tindakan yang telah disusun sebelumnya. Tindakan ini dimaksudkan untuk memperbaiki keadaan atau kegiatan pembelajaran di kelas yang belum sesuai dengan yang diharapkan.

Observasi, tahap observasi adalah mengamati seluruh proses tindakan dan pada saat selesai tindakan. Fokus observasi adalah aktivitas siswa. Aktivitas siswa dapat diamati mulai pada tahap pembelajaran, saat proses pembelajaran, dan akhir pembelajaran.

Refleksi dilakukan untuk mengkaji dan merenungkan kembali informasi informasi awal berkenaan dengan adanya ketidaksesuaian dengan praktek pembelajaran. Refleksi dilakukan berdasarkan hasil analisis data, baik observasi maupun data hasil evaluasi. Refleksi ini dilakukan secara bersama (kolaboratif) antara peneliti, teman sejawat, dan guru untuk menemukan bahan perbaikan untuk rencana tindakan selanjutnya. Apabila kriteria yang ditetapkan tecapai, maka siklus tindakan dihentikan. Sebaliknya, jika belum berhasil pada siklus tindakan tersebut, maka peneliti mengulang siklus tindakan dengan memperbaiki 
kinerja pembelajaran pada tindakan berikutnya sampai berhasil.

Dalam penelitian ini, analisis data dilakukan selama dan setelah penelitian, pada saat refleksi dari setiap tindakan pembelajaran. Teknik yang digunakan adalah teknik analisis data kualitatif yang dikembangkan oleh Miles dan Huberman (1992), yang terdiri dari tiga tahap kegiatan yaitu: 1) mereduksi data, 2) menyajikan data, dan 3) menarik kesimpulan dan verifikasi.

Analisa data disesuaikan dengan metode pengumpulannya dengan proses menyeleksi, menyederhanakan, memfokuskan, mengorganisasikan data secara sistematis dan rasional untuk menyajikan bahan-bahan yang dapat digunakan untuk menyusun jawaban masalah yang menjadi tujuan penelitian tindakan kelas.

Analisa data kuantitatif dari tes hasil belajar dilakukan dengan mencocokkan kunci/alternatif jawaban yang benar sesuai dengan konsep dari bidang ilmu yang bersesuaian. Kemudian disesuaikan dengan indikator keberhasilan untuk mengambil kesimpulan.

Pada penelitian tindakan kelas ini setiap siswa dianalisis hasil yang didapat dari setiap siklus. Peneliti membandingkan tentang prosentase ketuntasan belajar siswa dengan Kriteria Ketuntasan Minimal yang ditentukan dalam pelajaran IPA. Adapun tingkat ketuntasan belajar pada mata pelajaran tersebut di SDN 1 Ubung ditentukan pada nilai 65 . Siswa dikatakan tuntas apabila mendapat nilai $\geq 65$.

Data hasil observasi dianalisis dengan memberikan gambaran situasi yang terjadi saat pelaksanaan tindakan dalam bentuk kalimat. Data yang diperoleh pada lembar observasi kemudian dihitung prosentasenya. Hasil analisis data observasi per siklusnya akan memberikan gambaran mengenai perkembangan keaktifan siswa setelah dilakukan pembelajaran dan digunakan untuk merencanakan tindakan pada siklus selanjutnya.

Pengelolaan data kualitatif diambil dari data hasil aktivitas guru dengan siswa yang Jurnal Pendidikan Mandala diperoleh melalui lembar observasi, dianalisis dan dinyatakan dalam bentuk persentase yang dihitung dengan menggunakan rumus :

Persentase Nilai Rata-rata $=$ Jumlah Skor x $100 \%$ Skor Maksimal

$76 \%<\mathrm{NR}<100 \%$ : Sangat baik

$51 \%<\mathrm{NR}<75 \%$ : Baik

$26 \%<\mathrm{NR}<50 \%$ : Cukup

$0 \%<\mathrm{NR}<25 \%$ : Kurang Baik (Depdiknas, 2004).

Data kuantitatif diperoleh dari tes awal, tes akhir siklus I pertemuan 1 dan 2, serta tes akhir siklus II pertemuan 1 dan 2 .

\section{HASIL PENELITIAN}

Prasiklus

Sebelum diadakan perbaikan pembelajaran atau sebelum pelak-sanaan siklus I dan siklus II penulis terlebih dahulu melakukan identifi-kasi masalah pada proses pembelajaran Ilmu Pengetahuan Alam di kelas VI SDN 1 Ubung, peneliti melakukan observasi efektifitas media pembe-lajaran sebelumnya dengan cara memberikan tes formatif pada materi struktur kerangka tubuh manusia dan fungsinya. Hasil tes formatif menjelaskan bahwa siswa yang dinyatakan tuntas hanya 25\% (6 siswa) sedangkan $75 \%$ (18 siswa) dinyatakan belum tuntas atau dibawah KKM. Rendahnya tingkat penguasaan siswa terhadap materi ini, dapat dikatakan pembelajaran yang telah dilaksanakan kurang berhasil.

\section{Siklus I}

Dalam rangka implementasi tindakan perbaikan, pembelajaran IPA materi sistem organ tubuh manusia dan fungsinya siklus I ini dirancang dengan dua kali pertemuan. Alokasi waktu setiap pertemuan adalah 2 × 35 menit.

Pada proses pembelajaran peneliti menggunakan metode demonstrasi dan disesuaikan dengan rencana pelaksanaan pembelajaran (RPP). Selama proses belajar mengajar, peneliti mengikuti langkah-langkah menggunakan metode demonstrasi. Selain itu, peneliti dan subjek penelitian diamati dan dinilai oleh seorang guru kelas VI SDN 1 Ubung, 
dengan menggunakan lembar observasi aktivitas guru dan siswa. Disamping itu, peneliti juga melibatkan seorang teman untuk mendokumentasikan penelitian.

Setelah selesai pelaksanaan kegiatan pembelajaran tindakan siklus I, baik pada pertemuan pertama maupun pertemuan kedua dengan metode demonstrasi, kegiatan selanjutnya adalah pemberian tes untuk mengetahui hasil belajar siswa. Bentuk tes hasil belajar yang diberikan adalah uraian dengan jumlah 5 soal, tiap soal memiliki bobot 20 .

Hasil tes formatif pertemuan pertama menunjukkan bahwa persentase Ketuntasan Belajar Klasikal yang diperoleh adalah 25\% dengan ketuntasan jumlah siswa yang dinyatakan tuntas berjumlah 6 siswa dari jumlah keseluruhan siswa, yaitu 24 siswa. Hasil tersebut masih belum memenuhi kriteria persentase ketuntasan belajar klasikal, yakni sebesar $80 \%$. Adapun Daya Serap Klasikal yang diperoleh pada siklus I pertemuan pertama adalah 56\% dengan ketuntasan jumlah nilai yang diperoleh seluruh siswa sebanyak 1344 dari jumlah skor ideal yakni 2400 .

Pada lembar observasi aktivitas guru pada pertemuan pertama memperoleh persentase rata-rata $67 \%$ dengan kriteria baik sedangkan pada lembar observasi aktivitas siswa memperoleh persentase rata-rata $47 \%$ dengan kriteria kurang.

Dari hasil tes formatif pertemuan kedua Ketuntasan Belajar Klasikal yang diperoleh adalah 50\% dengan ketuntasan jumlah siswa yang dinyatakan tuntas berjumlah 12 siswa dari jumlah keseluruhan siswa, yaitu 24 siswa. Sedangkan Daya Serap Klasikal yang diperoleh pada siklus I pertemuan kedua adalah 61,25\% dengan ketuntasan jumlah nilai yang diperoleh seluruh siswa sebanyak 1470 dari jumlah skor ideal yakni 2400. Hasil tersebut masih belum mencapai indikator ketuntasan belajar secara klasikal yaitu sekurang-kurangnya $65 \%$. Sedangkan pada lembar observasi aktivitas guru di pertemuan kedua memperoleh persentase ratarata $75 \%$ dengan kriteria baik sedangkan pada lembar observasi aktivitas siswa memperoleh persentase rata-rata 58\% dengan kriteria kurang.

Jika ditinjau dari hasil tes formatif siklus I pertemuan kedua nampak ada sedikit peningkatan meskipun belum mencapai indikator ketuntasan yang telah ditetapkan. Untuk itu penelitian harus dilanjutkan pada pelaksanaan siklus II dengan cara melakukan perencanaan ulang berdasarkan kelemahankelemahan yang terjadi pada pelaksanaan tindakan pada siklus I, baik pada pertemuan pertama maupun pertemuan kedua.

\section{Siklus II}

Siklus II merupakan tindak lanjut dari siklus sebelumnya. Sebelum pelaksanaan siktus II ini, penulis terlebih dahulu merencanakan segala sesuatu yang nantinya digunakan dalam penelitian. Perencanaan tersebut diantaranya adalah mendiskusikan bersama observer untuk menentukan waktu pelaksanaan, membuat rencana pelaksanaan pembelajaran, merancang kegiatan belajar yang lebih baik dan membuat lembar pengamatan. Tindakan pada siklus II direncanakan selama 4 jam pelajaran dengan 2 kali pertemuan. Setiap pertemuan alokasi waktunya 2 jam pelajaran selama 70 menit. Setelah selesai pelaksanaan kegiatan pembelajaran tindakan siklus II baik pada pertemuan pertama maupun pertemuan kedua dengan metode demonstrasi, kegiatan selanjutnya adalah pemberian tes untuk mengetahui hasil belajar siswa. Bentuk tes hasil belajar yang diberikan adalah uraian dengan jumlah 5 soal, tiap soal memiliki bobot 20 .

Hasil belajar siswa pada siklus II pertemuan pertama diperoleh persentase Ketuntasan Belajar Klasikal pada sejumlah 75\% dengan ketuntasan jumlah siswa yang dinyatakan tuntas berjumlah 18 siswa dari 24 siswa. Hasil tersebut menandakan adanya peningkatan persentase yang signifikan. Pada lembar observasi aktivitas guru pertemuan pertama diperoleh persentase rata-rata $82 \%$ dengan kriteria sangat baik, sedangkan pada lembar observasi aktivitas siswa memperoleh persentase rata-rata $69 \%$ dengan kriteria penilaian baik. 
Sedangkan data hasil belajar siswa pada pertemuan kedua 2 diperoleh persentase Ketuntasan Belajar Klasikal sejumlah 92\% dengan ketuntasan jumlah siswa yang dinyatakan tuntas berjumlah 22 dari 24 siswa. dan hanya 2 siswa yang dinyatakan belum tuntas. Dari hasil tersebut maka ketuntasan belajar klasikal pada siklus II pertemuan 2 telah memenuhi kriteria persentase, yaitu lebih dari $80 \%$. Adapun Daya Serap Klasikal yang diperoleh pada siklus II pertemuan 2 adalah 93,3\% dengan ketuntasan jumlah nilai yang diperoleh seluruh siswa sebanyak 2240 dari jumlah skor ideal yakni 2400. Hasil tersebut menandakan adanya perubahan yang sangat signifikan, dimana dalam mencapai indikator ketuntasan belajar secara klasikal sekurangkurangnya $65 \%$.

Pada lembar observasi aktivitas guru pada pertemuan kedua siklus II memperoleh persentase rata-rata $87 \%$ dengan kriteria sangat baik, sedangkan pada lembar observasi aktivitas siswa memperoleh persentase rata-rata $82 \%$ dengan kriteria sangat baik.

\section{PEMBAHASAN}

Dalam rangka mengidentifikasi masalah pada proses pembelajaran Ilmu Pengetahuan Alam di kelas VI SDN 1 Ubung, peneliti melakukan observasi efektifitas media pembelajaran sebelumnya dengan cara memberikan tes formatif pada materi struktur kerangka tubuh manusia dan fungsinya. Hasil tes formatif menjelaskan bahwa siswa yang dinyatakan tuntas hanya $25 \%$ sedangkan $75 \%$ dinyatakan belum tuntas atau dibawah Kriteria Ketuntasan Minimal. Rendahnya tingkat penguasaan siswa terhadap materi ini, dapat dikatakan pembelajaran yang telah dilaksanakan kurang berhasil. Dari masalah tersebut yang menjadi refleksi penulis yaitu menggunakan metode pembelajaran demonstrasi yang efektif.

Pada proses perbaikan pembelajaran siklus I, peneliti mengguna-kan metode demonstrasi dengan menggunakan media gambar kerangka manusia. Adapun kriteria media gambar melipuri keaslian gambar yang Jurnal Pendidikan Mandala menunjukkan situasi dan kondisi sebenarnya, kesederhanaan warna yang mempunyai nilai estetis secara murni dan mengandung nilai praktis, mudah dipahami dan disesuaikan dengan tujuan yang hendak dicapai. Sedangkan pada siklus II, peneliti menggunakan metode demonstrasi dengan menggunakan media turso (patung organ manusia). Adapun kriteria media turso meliputi kesamaan bentuk benda sehingga memper-mudah siswa dalam memahami dan mendemonstrasikan.

Berdasarkan pengamatan dan analisis data nilai tes formatif dari setelah pelaksanaan perbaikan siklus I dan setelah diadakan perbaikan pembelajaran pada siklus II, dapat diketahui ada peningkatan nilai tes formatif yang cukup signifikan.

Pada perbaikan pembelajaran siklus I pertemuan pertama nilai ketuntasan belajar klasikal tes formatif adalah 25\%, dan setelah diadakan perbaikan pada siklus I pertemuan kedua ketuntasan belajar klasikal tes formatif menjadi $50 \%$. Meskipun ada peningkatan hasil belajar namun belum mencapai indikator keberhasilan yang diharapkan. Identifikasi masalah berada pada media pembelajaran berupa gambar yang sukar dipahami siswa, disisi lain metode demonstrasi masih asing bagi siswa sehingga siswa belum terbiasa dalam melakukan demonstrasi. Identifikasi ini dijadikan dasar perbaikan pembelajaran pada siklus selanjutnya.

Setelah dilakukan perbaikan pembelajaran siklus II pertemuan pertama dengan menggunakan media turso, nilai ketuntasan belajar klasikal meningkat menjadi $75 \%$, kemudian setelah diadakan perbaikan pembelajaran pada siklus II pertemuan kedua, maka ketuntasan belajar klasikal meningkat menjadi $92 \%$.

Kalau pada proses Pembelajaran Siklus I pertemuan 1 jumlah siswa yang tuntas adalah 6 siswa atau $25 \%$, maka setelah diadakan Perbaikan Pembelajaran siklus I pertemuan 2 jumlah siswa yang tuntas meningkat menjadi 12 siswa atau $50 \%$ dan setelah perbaikan pembelajaran siklus II pertemuan 1, jumlah 
siswa yang tuntas meningkat menjadi 18 siswa atau $75 \%$, dan setelah diadakan perbaikan pembelajaran siklus II pertemuan 2 jumlah siswa yang tuntas menjadi 22 siswa atau $92 \%$.

Adapun daftar tingkat daya serap klasikal baik pada perbaikan pembelajaran siklus I pertemuan 1 dan pertemuan 2, maupun setelah pelaksanaan perbaikan pembelajaran siklus II pertemuan 1 dan 2 hasilnya dapat dilihat pada tabeldi bawah ini.

Tabel 1: Tingkat daya serap klasikal sebelum dan sesudah perbaikan pembelajaran tiap siklus:

\begin{tabular}{|c|c|c|c|c|c|c|c|c|c|}
\hline \multirow{2}{*}{ No. } & \multirow{2}{*}{ Ketuntasan } & \multicolumn{2}{|c|}{$\begin{array}{c}\text { Sikius I } \\
\text { Pertemuan 1 }\end{array}$} & \multicolumn{2}{c|}{$\begin{array}{c}\text { Siklus I } \\
\text { Pertemuan 2 }\end{array}$} & \multicolumn{2}{c|}{$\begin{array}{c}\text { Sikus II } \\
\text { Pertemuan 1 }\end{array}$} & \multicolumn{2}{|c|}{$\begin{array}{c}\text { Siklus II } \\
\text { Pertemuan 2 }\end{array}$} \\
\cline { 3 - 10 } & & Iml & $\%$ & Iml & $\%$ & Iml & $\%$ & Iml & $\%$ \\
\hline 1 & Tuntas & 6 & 25 & 12 & 50 & 18 & 75 & 22 & 92 \\
\hline 2 & Belum & 18 & 75 & 12 & 50 & 6 & 25 & 2 & 8 \\
\hline 3 & Jumlah & 24 & 100 & 24 & 100 & 24 & 100 & 44 & 100 \\
\hline
\end{tabular}

Berdasarkan pada hasil yang diperoleh melalui penerapan metode demonstrasi dalam pembelajaran IPA sesuai dengan hasil penelitian yang dilaksanakan dalam dua siklus dapat meningkatkan hasil belajar siswa kelas VI SDN 1 Ubung pada Mata Pelajaran IPA. Hal tersebut tidak terlepas dari hasil observasi aktivitas guru maupun aktivitas siswa di setiap akhir siklus I dan siklus II yang tampak terjadi peningkatan dan mencapai indikator yang ditentukan. Peningkatan hasil penelitian yang telah dilakukan dapat dijelaskan sebagai berikut:

1. Aktifitas Guru

Aktifitas guru dalam setiap kali pertemuan baik, sehingga dapat dikatakan aktivitas guru pada pelaksanaan kegiatan belajar mengajar menurut observer dalam kategori baik pada siklus I dan kategori sangat baik pada siklus II. Siklus I petemuan 1 memperoleh persentase rata-rata $67 \%$ dan mengalami peningkatan pada siklus I pertemuan kedua dengan persentase rata-rata $75 \%$, begitu pula pada siklus II petemuan 1 memperoleh persentase rata-rata $82 \%$ dan mengalami peningkatan pada siklus II pertemuan 2 dengan persentase rata-rata sebesar $87 \%$.

\section{Aktivitas Siswa}

Jurnal Pendidikan Mandala
Aktivitas siswa menunjukan peningkatan dari Siklus I ke Siklus II dalam mengikuti pembelajaran, rata-rata dalam kategori kurang, baik dan sangat baik. Peningkatan ini terjadi karena kelemahan-kelemahan disiklus I dapat diminimalisir. Siklus I pertemuan pertama memperoleh persentase rata-rata sejumlah $47 \%$ dan mengalami peningkatan pada pertemuan kedua dengan persentase rata-rata sebesar 58\%. Pada siklus Siklus II pertemuan pertama memperoleh persentase rata-rata sejumlah $69 \%$ dan mengalami peningkatan yang cukup signifikan pada siklus II pertemuan kedua dengan persentase rata-rata sebesar $80 \%$ dengan indikator sangat baik.

\section{KESIMPULAN}

Berdasarkan hasil penelitian tindakan kelas yang telah dilaksanakan, maka penulis menyimpulkan hal-hal sebagai berikut :

1. Pelaksanaan pembelajaran dengan metode demonstrasi dinilai dapat meningkatkan hasil belajar IPA kelas VI SDN 1 Ubung tentang sistem organ tubuh manusia dan fungsinya. Hal ini dibuktikan dengan peningkatan ketuntasan belajar siswa dari setiap siklus. Pada kondisi pra siklus ketuntasan hanya mencapai 20,8\%, setelah dilakukan kegiatan perbaikan pembelajaran dengan menggunakan metode demonstrasi serta menggunakan media pembelajaran yang relevan, ketuntasan belajar siswa pada siklus I pertemuan 1 meningkat menjadi $25 \%$ (6 siswa), pada siklus I pertemuan 2 meningkat menjadi $50 \%$ (12 siswa), pada siklus II pertemuan 1 meningkat menjadi $75 \%$ (18 siswa) dan pada siklus II pertemuan 2 semakin meningkat menjadi $92 \%$ (22 siswa).

2. Bila dilihat dari aspek aktivitas siswa maupun aktivitas guru keduanya mengalami peningkatan dari kategori baik pada siklus I menjadi kategori sangat baik pada siklus II. Dengan demikian penggunaan metode demonstrasi dapat meningkatkan hasil belajar siswa kelas VI SDN 1 Ubung pada mata pelajaran Ilmu Pengetahuan Alam.

\section{SARAN}


Berdasarkan hasil penelitian tindakan kelas yang telah dilaksanakan, maka penulis menyarankan hal-hal sebagai berikut :

1. Guru hendaknya lebih aktif memilih dan menemukan ide-ide baru dalam penggunaan metode pembelajaran yang tepat, sehingga siswa mudah memahami konsep yang dipelajari. Disisi lain, sekolah hendaknya menyediakan sarana dan prasarana pembelajaran yang relevan guna menunjang upaya peningkatan pembelajaran yang efektif dan menyenangkan.

2. Selama proses pembelajaran sebaiknya guru lebih mementingkan aspek kompetensi dari pada aspek ingatan, karena kompetensi lebih tahan lama dan berguna bagi kehidupan siswa dimasa yang akan datang.

\section{DAFTAR PUSTAKA}

Arikunto, Suharsimi.(2006:84). Dasar-Dasar Evaluasi Pendidikan. Jakarta : Bumi Aksara.

Depdiknas, 2004. Penilaian. Jakarta : Direktorat Pendidikan Dasar dan Menengah, Departemen Pendidikan Nasional.

Muhlis, Mansur (2010). Melaksanakan PTK itu mudah (pedoman praktis bagi guru professional). Jakarta : Pustaka Pelajar.

Suprijono. (2011). Cooperative Learning. Jogjakarta : Pustaka Belajar

Triantono. (2010). Model pengajaran Terpadu. Bandung : Bumi Aksara. 